\title{
Priming pheromones from oestrous cows increase synchronization of oestrus in dairy heifers after PGF- $2 \alpha$ injection
}

\author{
M. K. Izard and J. G. Vandenbergh \\ Department of Zoology, North Carolina State University, Raleigh, North Carolina 27650, \\ U.S.A.
}

\begin{abstract}
Summary. Post-pubertal Holstein heifers with palpable corpora lutea were injected i.m. with $25 \mathrm{mg}$ PGF- $2 \alpha$ to bring all animals to the follicular phase of the oestrous cycle. After 3 oronasal treatments with secretions from oestrous cows or water, heifers were observed for oestrus and inseminated about $12 \mathrm{~h}$ after the onset of oestrus. In Exp. I, heifers were treated with water or a mixture of urine and cervical mucus from oestrous cows at 6,30 and $56 \mathrm{~h}$ after the PGF- $2 \alpha$ injection. The percentage of heifers in oestrus within $72 \mathrm{~h}$ after PGF-2 $\alpha$ was $86 \%$ for urine + cervical mucus-treated heifers and $60 \%$ for water-treated heifers $(P>0.05)$. Days to oestrus and conception rate after A.I. did not differ between the treatments. The degree of synchrony of oestrus after PGF-2 $\alpha$ was significantly greater $(P<0.05)$ in the animals receiving urine + mucus treatment.

In Exp. II, urine and cervical mucus from oestrous cows were separately tested in comparison to water. Test substances were applied at the time of PGF- $2 \alpha$ injection, and 6 and $30 \mathrm{~h}$ later. The percentage of heifers in oestrus within $72 \mathrm{~h}$ after PGF-2 $\alpha$ $(100 \%)$ was highest $(P<0.05)$ in the cervical mucus-treated heifers but the conception rate $(24 \%)$ was the lowest. The days to oestrus did not differ amongst groups but the degree of synchrony of oestrus after PGF-2 $\alpha$ was greatest $(P<0.05)$ in animals treated with cervical mucus. These data indicate that a priming pheromone in the cervical mucus of oestrous cows can affect the ovarian function of herdmates and thereby improve synchrony of oestrus after PGF- $2 \alpha$ injection.
\end{abstract}

\section{Introduction}

Pheromones are chemical messages secreted by one animal that cause a specific reaction in another individual of the same species. The response to a pheromone can involve either the performance of a certain behaviour, or a change in the physiology of the recipient (Karlson \& Butenandt, 1959).

Priming pheromones, those pheromones causing physiological changes (Wilson \& Bossert, 1963), have received much attention with respect to rodent reproduction (see reviews by Bronson, 1974; Vandenbergh, 1975, 1980). In the house mouse, for example, the onset of puberty in the female is accelerated by a component of male mouse urine (Vandenbergh, Finlayson, Dobrogosz, Dills \& Kost, 1976) and delayed by exposure to urine from grouped females (McIntosh \& Drickamer, 1977). Exposure to male mouse urine synchronizes the oestrous cycles of adult female house mice previously made anoestrous by grouping with other females (Bronson \& Whitten, 1968). Unlike female house mice, grouped female rats, or rats sharing a 
common air supply, exhibit a synchronization of oestrus that is mediated by an airborne chemical or pheromone (McClintock, 1978).

Some of the priming pheromonal systems described for rodents also operate in the reproductive systems of domestic animals. For example, the introduction of a ram into a flock of ewes at the onset of the breeding season synchronizes oestrus in the ewes (Underwood, Shier \& Davenport, 1944; Schinckel, 1954). A similar effect of the introduction of the male has been described in goats (Shelton, 1960). Exposure to a mature boar hastens the onset of puberty in gilts and has a synchronizing effect on their first oestrus (Hughes \& Cole, 1976). Treatment of post-partum sows with a synthetic signalling pheromone ('Boar Mate') has a priming effect, as it results in an earlier return to oestrus (Hillyer, 1976).

Although signalling pheromones are involved in the bull's recognition of and attraction to oestrous cows (Sambraus \& Waring, 1975; Paleologou, 1977; Jacobs et al., 1980), few studies indirectly or directly provide evidence for the involvement of priming pheromones in bovine reproduction. Petropavlovskĩ \& Rykova (1958) showed that exposure of post-partum cows to a vasectomized bull decreased the interval from parturition to conception by approximately 35 days, an effect that is probably pheromonal. Izard \& Vandenbergh (1982) provided direct evidence that a priming pheromone in bull urine has an effect on puberty in crossbred beef heifers: a larger percentage of prepubertal heifers receiving weekly oronasal treatments with bull urine reached puberty during the 7-week experimental period than did water-treated heifers.

Several studies have indicated that there are unknown exogenous environmental factors involved in the control of bovine ovarian function. Grouped cows with oestrous cycles synchronized by the use of synthetic progestagens or prostaglandin (PG) F-2 $\alpha$ appear to enhance cyclic activity in herdmates and the untreated cows in the same herd also show indications of having synchronized oestrous cycles (Weston, 1976; Weston \& Ulberg, 1976; Zimbelman, Lauderdale \& Moody, 1977). Priming pheromones from oestrous cows may be responsible for these reported effects on oestrus in herdmates.

Both urine and cervical mucus from oestrous cows are potential sources of priming pheromones. Urine is a basic medium used in mammalian chemical communication and contains sexually stimulating odours in many species (Shorey, 1976). Urine from oestrous cows stimulates sexual activity in bulls when applied to non-oestrous cows (Sambraus \& Waring, 1975), as does cervical mucus (Paleologou, 1977), which exhibits variations in the amount, consistency (Hammond, 1927), crystallization pattern (Alliston, Patterson \& Ulberg, 1958), protein content and peroxidase concentrations (Foulkes, Hartley \& Stewart, 1981) during the oestrous cycle.

In the present studies, PGF-2 $\alpha$ was used to synchronize the oestrous cycles of heifers with palpable corpora lutea $(C L)$. Although progesterone production by the $\mathrm{CL}$ declines rapidly and synchronously after PGF-2 $\alpha$ the subsequent onset of oestrus may be more variable (Nancarrow, Hearnshaw, Mattner, Connell \& Restall, 1974). Our hypothesis was that if synchrony of oestrus in cows is mediated by pheromones secreted by oestrous cows, then exposure to secretions containing those pheromones would increase the synchronization of oestrus obtained after PGF- $2 \alpha$ administration.

\section{Materials and Methods}

\section{General}

The experimental animals were post-pubertal Hoistein heifers (15-19 months of age and weighing at least $364 \mathrm{~kg}$ ) on two state-owned institutional dairy farms approximately $60 \mathrm{~km}$ apart. Heifers had palpable CL of at least $10 \mathrm{~mm}$ in diameter, and were injected i.m. with $25 \mathrm{mg}$ PGF-2 $\alpha$ (Upjohn) to regress the CL and bring the animals to the follicular phase of the oestrous cycle.

Cervical mucus and urine were collected from at least 2 oestrous cows. Cervical mucus was collected as it flowed from the vulva after rectal massage of the cervix. Urination was stimulated 
by massage of the external genitalia. Urine was vacuum filtered through a $0.45 \mu \mathrm{m}$ Millipore filter to remove debris and bacteria. For Exp. I, urine was mixed with cervical mucus at a 4 to 1 ratio $(\mathrm{v} / \mathrm{v})$, and frozen at $-16^{\circ} \mathrm{C}$ for a maximum of 1 week before use. For Exp. II, urine and cervical mucus were frozen separately up to 3 months before use.

Oronasal treatment with test substances occurred 3 times during the $54 \mathrm{~h}$ after PGF-2 $\alpha$ injection and a 1-ml syringe was used to apply the test substances. Half of each sample was sprayed into the nasal cavity and half was sprayed into the mouth. Therefore, test substances had access to both the accessory olfactory system and the olfactory system, both of which have been implicated in the mediation of the effects of priming pheromones (Estes, 1972; Wysocki, 1979; Johns, 1980).

The heifers were observed for oestrous behaviour for approximately $90 \mathrm{~min}$ in the early morning and late evening during the 5 days following PGF- $\alpha \alpha$ injection. In addition, brief checks for oestrus were made throughout the day and at least once each night. Heifers were scored as responders to PGF-2 $\alpha$ if they were in oestrus (i.e. stood to be mounted by another heifer in the group). The heifers were artificially inseminated with frozen commercial semen by farm personnel approximately $12 \mathrm{~h}$ after the onset of oestrus. Pregnancy diagnosis was performed via rectal palpation at least 32 days after insemination.

Oestrous response to PGF-2 $\alpha$, response within 72 h of PGF-2 $\alpha$ and conception rates were analysed by $\chi^{2}$ or Fisher's exact tests (Siegel, 1956) as appropriate. One-way analyses of variance were performed using the General Linear Models procedure for unbalanced data (Barr, Goodnight, Sall \& Helwig, 1976) to compare group means for days to oestrus. An F-test (Snedecor \& Cochran, 1967) was used to compare the variance of the distributions of the onset of oestrus after PGF- $2 \alpha$ as a means of determining the degree of oestrous synchrony.

\section{Experiment I}

Forty-seven heifers were studied during the summer of 1977. Control and experimental groups, consisting of 5-10 animals, were used sequentially between Farm A and Farm B until three replicates were completed. At 6,30 and 54 h after PGF- $2 \alpha$ injection, 25 heifers were exposed to $1 \mathrm{ml}$ of a mixture of cervical mucus and urine (see above). The 22 control heifers were treated similarly with $1 \mathrm{ml}$ water. Twice-daily observation for oestrous behaviour began 48 $\mathrm{h}$ after PGF-2 $\alpha$ injection and continued for $72 \mathrm{~h}$.

\section{Experiment II}

Ninety-two heifers were studied during the summer, fall and winter of 1979 and the spring, summer and fall of 1980 . Groups of 3-9 heifers, treated with water, urine or cervical mucus were used sequentially on Farms A and B until 6 replicates were completed. Test substances $(1 \mathrm{ml}$ water, $1 \mathrm{ml}$ urine or $0.5 \mathrm{ml}$ cervical mucus) were applied at the time of PGF-2 $\alpha$ injection, 6 and $30 \mathrm{~h}$ later. We selected an earlier time sequence for treatment because in Exp. I some heifers had already come into oestrus by the third treatment. Twice-daily observation for oestrous behaviour began $36 \mathrm{~h}$ after PGF-2 $\alpha$ injection and continued for $72 \mathrm{~h}$.

\section{Experiment I}

\section{Results}

A comparison of heifers treated with water or with a mixture of urine and cervical mucus showed no statistically significant differences in percentage of heifers detected in oestrus after PGF-2 $\alpha$ injection (Table 1). While there were also no significant differences in mean days to oestrus, there was a tendency for more of the heifers exposed to urine and mucus to have shown 
oestrus within $72 \mathrm{~h}$ of PGF-2 $\alpha$ injection $(0.05<P<0.01)$ (Table 1). The distributions of the onset of oestrus differed significantly between treatment groups, with the urine + cervical mucus-treated heifers showing a more synchronized onset of oestrus, as measured by a comparison of the variances of the mean days to oestrus for treatment groups $(\mathrm{F}=$ $0.6738 / 0.2538$; d.f. $=14,21 ; P<0.05$ ) (Text-fig. 1). Conception rates did not differ between treatment groups (Table 1).
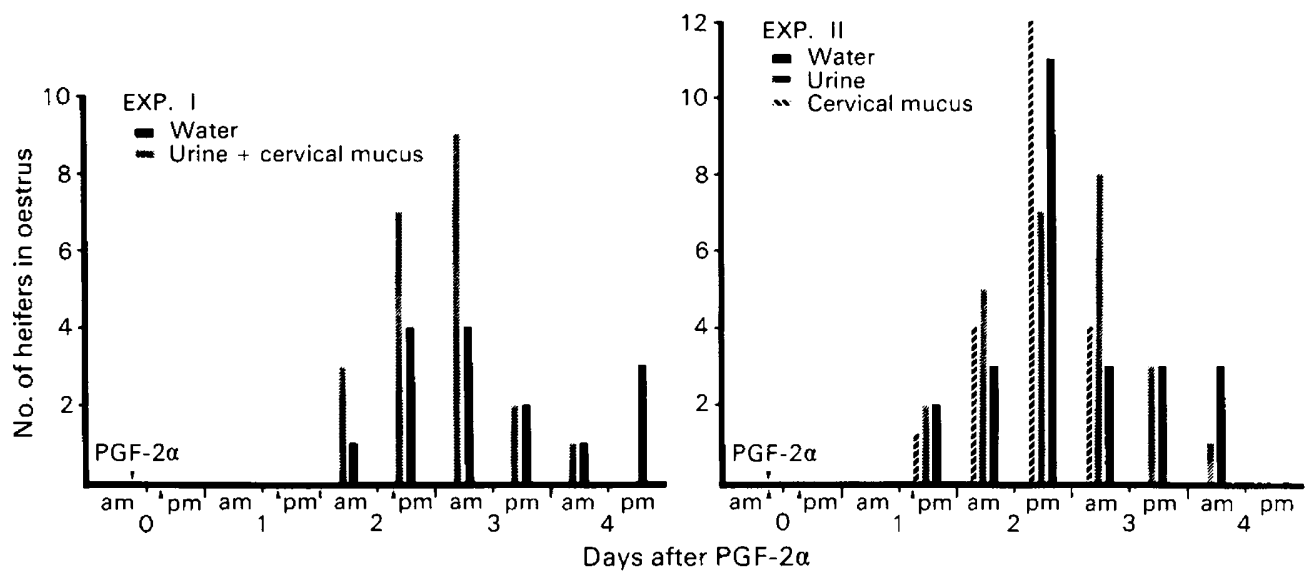

Text-fig. 1. Timing of the onset of oestrus in heifers after PGF-2 $\alpha$ injection. Heifers were exposed to water or urine and/or cervical mucus from oestrous cows as indicated by the arrows.

Table 1. The effect on heifers of oronasal treatment with water or urine + cervical mucus after PGF-2 $\alpha$ injection (Exp. I)

\begin{tabular}{lcc}
\hline & \multicolumn{2}{c}{ Treatment } \\
\cline { 2 - 3 } Variable & Water & Urine + mucus \\
\hline $\begin{array}{l}\text { No. of heifers } \\
\text { No. of heifers responding to }\end{array}$ & 22 & 25 \\
$\quad \begin{array}{l}\text { PGF-2 } \alpha / \text { no. treated (\%) } \\
\text { No. of heifers in oestrus within } 72 \mathrm{~h} \\
\quad \text { of PGF-2 } \alpha / \text { no. responding (\%) }\end{array}$ & $9 / 15(60)$ & $19 / 22(86)$ \\
$\begin{array}{l}\text { Days to oestrus (mean } \pm \text { s.d.) } \\
\text { No. of heifers pregnant } / \text { no. inseminated } \\
\quad \text { (conception rate \%) }\end{array}$ & $3.2 \pm 0.8$ & $2 \cdot 8 \pm 0.5$ \\
& & \\
\hline
\end{tabular}

\section{Experiment $I I$}

There were no significant differences in the percentage of heifers detected in oestrus after PGF-2 $\alpha$ (Table 2). Although there were no differences in mean days to oestrus, there were differences in the numbers of animals showing oestrus within $72 \mathrm{~h}$ of PGF-2 $\alpha$ injection. The distributions of the onset of oestrus differed significantly between treatment groups, with cervical mucus-treated heifers showing a more synchronized onset of oestrus than did water-treated heifers $(\mathrm{F}=0.5017 / 0 \cdot 1476$; d.f. $=24,20 ; P<0.01)$ (Text-fig. 1$)$ or urine-treated heifers $(\mathrm{F}=$ $0.3954 / 0.1476$; d.f. $=25,20 ; P<0.05$ ) (Text-fig. 1 ). However, the conception rate in cervical mucus-treated heifers was the lowest. Two urine-treated heifers on one farm were not inseminated because of an oversight by farm personnel, and were eliminated from conception 
Table 2. The effect on heifers of oronasal treatment with water, urine or cervical mucus after PGF-2 $\alpha$ treatment (Exp. II)

\begin{tabular}{|c|c|c|c|}
\hline \multirow[b]{2}{*}{ Variable } & \multicolumn{3}{|c|}{ Treatment } \\
\hline & Water & Urine & Cervical mucus \\
\hline No. of heifers & 32 & 31 & 29 \\
\hline $\begin{array}{l}\text { No. of heifers responding to } \\
\text { PGF- } 2 \alpha / \text { no. treated (\%) }\end{array}$ & $25 / 32(78)$ & $26 / 31(84)$ & $21 / 29(72)$ \\
\hline $\begin{array}{l}\text { No. of responding heifers in oestrus } \\
\text { within } 72 \mathrm{~h} \text { of PGF- } 2 \alpha \text { no. } \\
\text { responding (\%) }\end{array}$ & $19 / 25(76)$ & $22 / 26(85)$ & $21 / 21(100)^{*}$ \\
\hline Days to oestrus (mean \pm s.d.) & $2 \cdot 7 \pm 0.7$ & $2.6 \pm 0.6$ & $2.4 \pm 0.4$ \\
\hline $\begin{array}{l}\text { No. of heifers pregnant/no. inseminated } \\
\text { (conception rate \%) }\end{array}$ & $16 / 25(64)$ & $14 / 24(58)$ & $5 / 21(24) \dagger$ \\
\hline
\end{tabular}

rate calculations. Second service conception rates were 56,60 and $30 \%$ for heifers treated with cervical mucus, urine and water, respectively.

\section{Discussion}

In Exps I and II, the percentages of heifers showing oestrus within 5 days of PGF- $2 \alpha$ treatment are in agreement with values reported in the literature (Roche, 1974; Peters, Welch, Lauderdale \& Inskeep, 1977).

The average number of days to oestrus after PGF- $2 \alpha$ did not change with treatment. Most heifers showed oestrus on the evening of Day 2 or the morning of Day 3 after PGF-2 $\alpha$, which is in agreement with values reported in the literature (Welch et al., 1975; Peters et al., 1977; Britt, Hafs \& Stevenson, 1978). The most striking effect of treatment with cervical mucus in combination with urine (Exp. I) or alone (Exp. II) was an increased synchronization of oestrus although the average time to onset of oestrus was not affected. This effect of cervical mucus on ovarian functions suggests that cervical mucus contains a priming pheromone.

How this putative priming pheromone could increase oestrous synchronization after PGF- $2 \alpha$ is unclear. To change the timing of oestrus, a pheromone probably would not affect the decline in progesterone levels seen after PGF-2 $\alpha$ injection, as this decline is rapid and relatively imperturbable (Chenault, Thatcher, Kalra, Abrams \& Wilcox, 1974; Nancarrow et al., 1974). In addition, direct pheromonal influences on the bovine ovary are unlikely, as rodent priming pheromones consistently exert their effects on the hypothalamic-pituitary complex (Bronson \& Desjardins, 1969, 1974; Chapman, Desjardins \& Whitten, 1970). The pheromone may indirectly affect ovarian oestrogen production or influence the responsiveness of the hypothalamus to ovarian oestrogens. The pheromone might itself be an oestrogenic substance. Oestradiol benzoate given $48 \mathrm{~h}$ after PGF- $2 \alpha$ increases the occurrence of oestrus within a specific target period (Peters et al., 1977), while the same hormone given $28 \mathrm{~h}$ after PGF- $2 \alpha$ significantly shortens the time to oestrus (Nancarrow \& Radford, 1975). To our knowledge, the oestrogen content of cervical mucus has not been examined. Although urine from oestrous cows contains oestrogens (Mellin \& Erb, 1966), in Exp. II urine did not significantly increase the synchronization of oestrus after PGF-2 $\alpha$ over that of water-treated animals.

If an oestrus synchronizing pheromone is present in the cervical mucus of oestrous cows, within-group pheromonal stimulation may have occurred amongst the oestrous heifers in the 
control groups. Therefore, if isolation of control animals had been possible, we would have expected to see an even greater difference between experimental and control groups with respect to synchrony of oestrus. Unfortunately, lack of facilities, difficulties in management of isolated animals and problems in detecting oestrus in isolated animals made the optimum control impossible. The differences that were seen may have occurred because the treated heifers had the pheromone applied directly to the oral and nasal cavities instead of being diffusely available in the environment.

Conception rates obtained with artificial insemination after PGF- $2 \alpha$ injection have ranged from 46 to $75 \%$ (Oxender, Noden, Louis \& Hafs, 1974; Peters et al., 1977). The conception rates reported here are comparable to values found by others, with the exception of the conception rate in mucus-treated heifers in Exp. II. The low conception rate in this group was a consistent phenomenon across farms, inseminators and seasons. The effect of cervical mucus on conception rate was not a long-term effect, because second-service conception rates were as high or higher than those in urine- or water-treated heifers.

It is puzzling that heifers in Exp. I that were treated with a mixture of cervical mucus and urine did not show the same decline in conception rate when compared with controls as was seen in heifers in Exp. II that were treated with cervical mucus alone. Two major differences between Exp. I and Exp. II may account for this. In Exp. I, heifers were exposed to $0.2 \mathrm{ml}$ cervical mucus at each exposure time, while heifers in Exp. II were exposed to $0.5 \mathrm{ml}$. In addition, exposure to cervical mucus occurred at different times after PGF- $2 \alpha$ in the two experiments. Treatment with cervical mucus may have disturbed the relationship between onset of oestrus and ovulation, so that A.I. occurred at an inappropriate time in the follicular phase, but how cervical mucus could have such an effect is unclear. Further investigation into the dosage of mucus and the timing of exposure to it after PGF- $2 \alpha$ is needed.

Although prostaglandins are useful exogenous synchronizing agents, they do not provide precise control of the oestrous cycle (Roche, 1974). The aim of oestrous synchronization is to facilitate the use of A.I. by controlling the day that oestrus occurs. However, the degree of synchrony presently obtainable with PGF- $2 \alpha$ yields variable conception rates, usually low, if A.I. is performed at a set time without regard to oestrus (Cooper \& Walpole, 1975; Peters et al., 1977; Burfening, Anderson, Kinkie, Williams \& Friedrich, 1978). Increasing the degree of synchrony after PGF-2 $\alpha$ should improve conception rates with set-time A.I. (Johnson, 1978; Refsal \& Seguin, 1980). If PGF-2 $\alpha$-treated animals are inseminated in relationship to the onset of oestrus, fertility is comparable to that of untreated controls (Peters et al., 1977), but oestrus must be detected. Hurnik, King \& Robertson (1975) have shown that as the number of animals in oestrus at the same time increases, oestrous behaviour also increases, possibly improving detection of oestrus in the herd. Therefore, a pheromone produced in the cervical mucus of oestrous cows that can affect ovarian function so that oestrous synchronization is increased has potential for use when A.I. is performed at a set time or in relation to the onset of oestrus.

We thank Clarence Marsh of the Reproductive Physiology Research Laboratory at North Carolina State University and the farm personnel at Dorothea Dix and John Umstead State Institutional farms for technical assistance; Dr J. W. Lauderdale (Upjohn) for PGF-2 $\alpha$; and especially Dr L. C. Ulberg, Department of Animal Science, North Carolina State University, for his participation in all phases of this research. This work forms parts of theses submitted by M.K.I. to North Carolina State University in partial fulfilment of the requirements for the M.S. and Ph.D. degrees. Paper number 6412 of the Journal series of the North Carolina Agricultural Research Service, Raleigh.

\section{References}

Alliston, C.W., Patterson, T.B. \& Ulberg, L.C. (1958) Crystallization patterns of cervical mucus as related to estrus in beef cattle. J. Anim. Sci. 17, 322-325.
Barr, A.J., Goodnight, J.H., Sall, J.P. \& Helwig, J.T. (1976) A User's Guide to SAS. Sparks Press, Raleigh. 
Britt, J.H., Hafs, H.D. \& Stevenson, J.S. (1978) Estrus in relation to time of administration of prostaglandin$\mathrm{F}_{211}$ to heifers. J. Dairy Sci. 61, 513-515.

Bronson, F.H. (1974) Pheromonal influences on reproductive activities in rodents. In Pheromones, pp. 344-365. Ed. M. C. Birch. North Holland, Amsterdam.

Bronson, F.H. \& Desjardins, C. (1969) Release of gonadotrophin in ovariectomized mice after exposure to males. J. Endocr. 44, 293-297.

Bronson, F.H. \& Desjardins, C. (1974) Circulating concentrations of $\mathrm{FSH}, \mathrm{LH}$, estradiol and progesterone associated with acute, male-induced puberty in female mice. Endocrinology 94, 16581668.

Bronson, F.H. \& Whitten, W.K. (1968) Oestrusaccelerating pheromone of mice: assay, androgendependency and presence in bladder urine. J. Reprod. Fert. 15, 131-134.

Burfening, P.J., Anderson, D.C., Kinkie, R.A., Williams, J. \& Friedrich, R.L. (1978) Syncronization of estrus with $\mathrm{PGF}_{2 \alpha}$ in beef cattle. J. Anim. Sci. 47, 999-1003.

Chapman, V.M., Desjardins, C. \& Whitten, W.K. (1970) Pregnancy block in mice: changes in pituitary LH and LTH and plasma progestin levels. J. Reprod. Fert. 21, 333-337.

Chenault, J.R., Thatcher, W.W., Kalra, P.S., Abrams, R.M. \& Wilcox, C.J. (1974) Hormonal changes in the bovine induced by $\mathrm{PGF}_{2 \alpha} J$. Anim. Sci. 39, 202, Abstr.

Cooper, M.J. \& Walpole, A.L. (1975) Practical application of prostaglandins in animal husbandry. In Prostaglandins and Reproduction, pp. 309-328. Ed. S. M. M. Karim. University Park Press, Baltimore.

Estes, R.D. (1972) The role of the vomeronasal organ in mammalian reproduction. Mammalia 36, 315-341.

Foulkes, J.A., Hartley, P.E. \& Stewart, D.L. (1981) Bovine cervical mucus peroxidase concentrations at oestrus. Res. vet. Sci. 30, 14-17.

Hammond, J. (1927) The Physiology of Reproduction in the Cow. Cambridge University Press.

Hillyer, G.M. (1976) An investigation using a synthetic porcine pheromone and the effect on days from weaning to conception. Vet. Rec. 98, 93-94.

Hughes, P.E. \& Cole, D.J.A. (1976) Reproduction in the gilt. 2. The influence of gilt age at boar introduction on the attainment of puberty. Anim. Prod. 23, 89-94.

Hurnik, J.F., King, G.J. \& Robertson, H.A. (1975) Estrous and related behaviour in postpartum Holstein cows. Appl. Anim. Ethol. 2, 55-68.

lzard, M.K. \& Vandenbergh, J.G. (1982) The effects of bull urine on puberty and calving date in crossbred beef heifers. J. Anim. Sci. (in press).

Jacobs, V.L., Sis, R.F., Chenoweth, P.J., Klemm, W.R., Sherry, C.J. \& Coppock, C.E. (1980) Tongue manipulations of the palate assists estrous detection in the bovine. Theriogenology 13, 353-356.

Johns, M.A. (1980) The role of the vomeronasal system in mammalian reproductive physiology. In Chemical Signals: Vertebrates and Aquatic Invertebrates, pp. 341-364. Eds D. Muller-Schwarze \& R. M. Silverstein. Plenum, New York.

Johnson, C.T. (1978) Time to onset of oestrus after the injection of heifers with cloprostenol. Vet. Rec. 103, 204-206.
Karlson, P. \& Butenandt, A. (1959) Pheromones (ectohormones) in insects. Ann. Rev. Entomol. 4, 39-58.

McClintock, M.K. (1978) Estrous synchrony and its mediation by airborne chemical communication (Rattus norvegicus). Horm. Behav. 10, 264-276.

McIntosh, T.K. \& Drickamer, L.C. (1977) Excreted urine, bladder urine, and the delay of sexual maturation in female house mice. Anim. Behav. 25, 999-1004.

Mellin, T.N. \& Erb, R.E. (1966) Estrogen metabolism and excretion during the bovine estrous cycle. Steroids 7, 589-606.

Nancarrow, C.D. \& Radford, H.M. (1975) Use of oestradiol benzoate to improve synchronization of oestrus in cattle. J. Reprod. Fert. 43, 404, Abstr.

Nancarrow, C.D., Hearnshaw, H., Mattner, P.E., Connell, P.J. \& Restall, B.J. (1974) Hormonal changes occurring in cattle following the administration of prostaglandin $\mathrm{F}_{2 \alpha}$. J. Reprod. Fert. 36, 484, Abstr.

Oxender, W.D., Noden, P.A., Louis, T.M. \& Hafs, H.D. (1974) A review of prostaglandin $F_{2 i}$ for ovulation control in cows and mares. Am. J. Vet. Res. 35, 997-1001.

Paleologou, A.M. (1977) Detecting oestrus in cows by a method based on bovine sex pheromones. Vet. Rec. 100, 319-320.

Peters, J.B., Weich, J.A., Lauderdale, J.W. \& Inskeep, E.K. (1977) Synchronization of estrus in beef cattle with $\mathrm{PGF}_{2 \alpha}$ and estradiol benzoate. J. Anim. Sci. $45,230-235$.

Petropavlovskif, V.V. \& Rykova, A.I. (1958) The stimulation of sexual functions in cows. Anim. Br. Abstr. 27, 798.

Refsal, K.R. \& Seguin, B.E. (1980) Effect of stage of diestrus and number of cloprostenol (ICI 80,996) injections on intervals to estrus, $\mathrm{LH}$ peak and ovulation in heifers. Theriogenology 14, 37-48.

Roche, J.F. (1974) Synchronization of oestrus and fertility following artifical insemination in heifers given prostaglandin $\mathrm{F}_{2 \alpha} . J$. Reprod. Fert. 37, $135-138$.

Sambraus, H.H. \& Waring, G.H. (1975) Effect of urine from estrous cows on libido in bulls. Z. Saugetierk. 40, 49.

Schinckel, P.G. (1954) The effect of the ram on the incidence and occurrence of oestrus in ewes. Aust. vet. J. 30, 189-195.

Shelton, M. (1960) Influence of the presence of a male goat on the initiation of oestrus, cycling and ovulation of Angora does. J. Anim. Sci. 19, 368-375.

Shorey, H.H. (1976) Animal Communication by Pheromones. Academic Press, New York.

Siegel, S. (1956) Nonparametric Statistics for the Behavioral Sciences. McGraw-Hill, New York.

Snedecor, G.W. \& Cochran, W.G. (1967) Statistical Methods, 6th edn. Iow State University Press, Ames.

Underwood, E.J., Shier, F.L. \& Davenport, N. (1944) Studies in sheep husbandry in Western Australia. V. The breeding season of Merino, crossbred and British breed ewes in the agricultural districts. J. Dep. Agric. West Aust., 2nd Series 21, 135-143.

Vandenbergh, J.G. (1975) Hormones, pheromones and behavior. In Hormonal Correlates of Behavior, Vol. 1: A Lifespan View, pp. 551-584. Eds B. E. Eleftheriou \& R. L. Sprott. Plenum Press, New York. 
Vandenbergh, J.G. (1980) The influence of pheronomes on puberty. In Chemical Signals in Vertebrates and Aquatic Invertebrates, pp. 229-241. Eds D. Muller-Schwarze \& R. M. Silverstein. Plenum Press, New York.

Vandenbergh, J.G., Finlayson, J.S., Dobrogosz, W.J., Dills, S.S. \& Kost, T.A. (1976) Chromatographic separation of puberty accelerating pheromone from male mouse urine. Biol. Reprod. 15, 260-265.

Welch, J.A., Hackett, A.J., Cunningham, C.J., Heishman, J.O., Ford, S.P., Nadaraja, R., Hansel, W. \& Inskeep, E.K. (1975) Control of estrus in lactating beef cows with prostaglandin $\mathrm{F}_{2 a}$ and estradiol benzoate. J. Anim. Sci. 41, 1686-1692.

Weston, J.S. (1976) Effects of management systems upon estrus detection and reproductive efficiency in dairy herds. M.S. thesis, North Carolina State University, Raleigh.

Weston, J.S. \& Ulberg, L.C. (1976) Responses of dairy cows to the behavior of treated herdmates during the postpartum period. J. Dairy Sci. 59, 1985-1988.

Wilson, E.o. \& Bossert, W.H. (1963) Chemical communication among animals. Recent Prog. Horm. Res. 19, 673-710.

Wysocki, C.J. (1979) Neurobehavioral evidence for the involvement of the vomeronasal system in mammalian reproduction. Neurosci. Biobehav. Rev. 3, 301-345.

Zimbelman, R.G., Lauderdale, J.W. \& Moody, E.L. (1977) Beef A.I. and prostaglandin $\mathrm{F}_{2 \alpha}$. Proc. 11th Conf. A.I. Beef Cattle, Denver, Colorado, pp. 66-75.

Received 18 November 1981 